\title{
FORMULATION OF THE DEVELOPMENT STRATEGY OF AN ORGANIZATION USING A SWOT ANALYSIS
}

\author{
Arys Susanto, Arica Dwi Susanto, Avando Bastari \\ Indonesian Naval Technology College \\ Bumimoro-Morokrembangan, Surabaya 60187, Indonesia
}

\begin{abstract}
This requires an organization to be able to compete by always paying attention to the user's condition. Development strategy is one way to find out competitiveness in each of its power lines. To deal with user competition, especially in the face of global users, an organization must be able to establish a method as the basic foundation for the formulation of development strategies by increasing the value of competitiveness for its output or services. This strategy needs to be involved using the SWOT method as the main method to increase output, internal and external factors become the initial steps to carry out strategies to optimize business to achieve success. The use of an effective SWOT analysis can play an important role in determining the development strategy, in order to know the strengths, weaknesses, opportunities and threats faced by the company in maintaining the survival and continuity of the organization. The problem that the answer in this research is looking for is whether the SWOT analysis is the right strategy to increase output in the organization and how the development strategy applied by the organization in overcoming global friendships. In connection with these problems the following hypothesis is proposed: It is suspected that using a SWOT analysis can increase output so that the organization experiences a profit (surplus). This study uses primary data by providing questionnaires and secondary data to obtain archives or documents. In line with the problem and the research hypothesis, this study was conducted using the IFAS analysis method to analyze internal factors, EFAS analysis for external factors, then, included in the quantitative model, namely the SWOT matrix. The results of the analysis show that, using IFAS and EFAS analysis and using SWOT analysis shows the position of the organization in cell 2, the strategy chosen to support the achievement of the objectives of the organization is ST strategy.
\end{abstract}

Keywords: SWOT, Strategy, Product Marketing, Business.

\section{INTRODUCTION}

Today, countries in the world seem to be without any boundaries and time and space limits, which are predicted to change the user's orientation. If previously the developing user orientation is an organization that can freely impose its will on the user with output outputs, which sometimes are not in accordance with the wishes of the user, then what happens now is the opposite (Till, 2015). The orientation shift is that entrepreneurs have fully realized that in today's global world, users are the holders of control over output and there are users, the user determines the type and form of output as what the diuser can or does, thus an organization as if " forced "to follow and produce output in accordance with the values and desires of the user if they still want to survive survive (Pershing, 2006). According to one source, it is estimated that the number of organizations reaches more than 12,000 organizations throughout the country. As a result, business competition is getting tougher. To address this, various efforts are needed (Hutabarat, 2017). The best step to maintain and or expand the user is to keep up with the latest technological developments. However, this step must be followed by educating users through offering comprehensive solutions.

This paper used some literature to support the research, for example paper with title Strengths,
Weaknesses, Opportunities And Threats (SWOT) Analysis On Globacom Ltd (Bello, 2013). Strengths vs Strong Position: Rethinking the Nature of SWOT Analysis (Clardy, 2013). SWOT Analysis of strategic Position of Cycling Federation in Iran (Arefeh Jamshidi, 2012). Comparing AHP and ANP: An Application of Strategic Decisions Making in a Manufacturing Company (GÖRENER, 2012). SWOT Analysis (Lalitha Chavali, 2017). The Strategic Planning (SWOT) Analysis Outcomes And Suggestions According To The Students And The Lecturers Within The Distance Education System (Tugba Yanpar YELKEN, 2012). Coping with Imprecision in Strategic Planning: A Case Study Using Fuzzy SWOT Analysis (Hasan HosseiniNasab, 2011). Strategic Planning \& SWOT Analysis (Kotnal, 2017). SWOT Balanced Scorecard (Rangkuti., 2012). Strategic development and SWOT analysis at the University of Warwick (Dyson, 2004). Combining SWOT and AHP Techniques for strategic planning (Osuna \& Aranda, 2007). Prioritiation of e-Govrnment strategies using a SWOT-AHP analysis: the case of Turkey (Kahraman, Cetin, \& Demirel, 2007). Studying strategies of sport management using SWOT technique (Leila Asayesh, 2013). Focused SWOT: diagnosing critical strengths and weaknesses (Ronen, 2009). A Synthesis on SWOT Analysis of Public Sector Healthcare Knowledge Management 
Information Systems in Pakistan (Arfan Arshad, 2017). A SWOT Analysis Tool For Indonesian Small and Medium Enterprise (Husni Thamrin, 2017). Development of Strategic Plan for Hotel Industries through Swot Analysis (C.Kiritharan nair, 2016). Importance-Performance Analysis based SWOT analysis (Boonyarat Phadermrod, 2016).

So, the function of the SWOT analysis and development strategy is to analyze the strengths, weaknesses and development advantages possessed by the organization / business carried out through an analysis of the internal conditions of the organization, as well as an analysis of the opportunities and threats faced by the organization through analysis of the external conditions (Sentot Patria. W. S, 2018). A developing organization is an organization that is demanded to be able to adjust user needs in a large scale. One of the efforts made by an organization is to increase efficiency and output in order to stay in competition with the user or even increase profitability. In situations of competition and challenges due to the constantly changing situation today, increasing efficiency and output is certainly desired by every organization. Increased efficiency and output are expected to increase profit margins significantly (Arys Susanto, 2018). Factors of strength, weakness, opportunity and threat are dynamic factors in SWOT (Strength, Weakness, Opportunity, and Threat) that can describe the ability of an organization to optimize and allocate using its resources and the situation faced in an effort to achieve a goal. Based on the above background, the authors are interested in taking the research title "Swot analysis to formulate a development strategy for an organization".

This Paper is organized as follows. Section 2 is review about the basic ship theory. Section 3 would be about the result of the research and section 4 discussion of research. Finally, while in section 5 we would present the conclusions of this paper.

\section{MATERIALS AND METHODS}

\subsection{Developmental Strategy}

Before it was stated about the determination of the development strategy, first an understanding of the strategy would be put forward. Strategy is a tool to achieve goals (Ussahawanitchakit, 2011). Whereas the other notions of strategy are incremental actions (always increasing) and continuously and carried out based on the point of view of what is expected by future customers, strategy (strategy) explicitly, namely the action plan that explains about allocation of resources and various activities to deal with the environment, obtain competitive advantage, and achieve organizational goals (Volkova, 2015). Defines competitive advantage is the thing that distinguishes an organization from other companies and gives a characteristic to the organization to meet user needs the user. The core strategy formulation is determining how our organization will be different from other organizations. The strategy of course changes over time according to environmental conditions, but in order to continue to develop (Pereira, 2015). Make a corporate strategy that focuses on: Utilization of basic competencies, Develop synergy, Creating Value for Customers

\subsection{SWOT Analysis}

SWOT analysis (SWOT analysis) which includes efforts to recognize strengths, weaknesses, opportunities, and threats that determine organizational performance (Hajikhani \& Jafari, 2013). External information about opportunities and threats can be obtained from many sources, including customers, government documents, suppliers, banks, other organized partners. Many organizations use the services of an institution to obtain newspaper multiples, research on the internet, and analysis of relevant domestic and global trends (Yogi, Rizal, \& Ahmadi, 2017). Furthermore explains that SWOT Analysis is a systematic identification of various factors to formulate organizational strategy. This analysis is based on logic that can maximize strengths and opportunities, but simultaneously can minimize weaknesses and threats. The strategy decision making process is always related to the development of the organization's mission, goals, strategies and policies. Thus, strategic planning must analyze the factors of the organization's strategy (strengths, weaknesses, opportunities and threats) in the current conditions (Lumaksono, 2014).

SWOT analysis compares the factors of external opportunities (opportunities) and threats (threats) with internal factors strengths (strenght) and weaknesses (weakness). SWOT elements consist of: Strength (Strength), Weakness (weakness), Opportunity (Opportunity), Threats (Threats), External and internal factors to analyze more deeply about SWOT, it is necessary to look at the factors external and internal as an important part of the SWOT analysis, namely: (Chermack \& Kasshanna, 2007).

\section{a. External factors}

This external factor influences the formation of opportunities and threats $(\mathrm{O}$ and $\mathrm{T})$. Where this factor concerns the conditions that occur outside the organization that influence organizational decision making. This factor covers the industrial and macro environment, economy, politics, law, technology, population, and socio-cultural environment.

\section{b. Internal factors}

This internal factor affects the formation of strenghts and weaknesses (S and W). Where this factor concerns the conditions that occur in the organization, which this also influences the formation of organizational decision making. These internal factors cover all kinds of functional management: marketing, finance, operations, human resources, research and development, 
management information systems and organizational culture.

\subsection{SWOT Analysis Model}

SWOT analysis compares between external opportunities and threats with internal factors of strengths and weaknesses. Internal factors are included in the matrix called the internal strategy factor matrix or IFAS (Internal Strategic Factor Analysis Summary). External factors are included in the matrix called the EFAS external strategy factor matrix (External Strategic Factor Analysis Summary).

After the internal and external strategy factor matrix was completed, the results were included in the quantitative model, namely the SWOT matrix to formulate an organizational development strategy (Setiarso, 2018).

\begin{tabular}{|l|c|c|c|l|}
\hline $\begin{array}{l}\text { Eksternal } \\
\text { strategy } \\
\text { factor }\end{array}$ & Weight & Rating & $\begin{array}{l}\text { Weight } \\
\text { X } \\
\text { rating }\end{array}$ & Information \\
\hline Opportunity & $\mathbf{X}$ & $\mathbf{X}$ & $\mathbf{X}$ & \\
\hline Total & $\mathbf{X}$ & $\mathbf{X}$ & $\mathbf{X}$ & \\
\hline Threat & $\mathbf{X}$ & $\mathbf{X}$ & $\mathbf{X}$ & \\
\hline Total & $\mathbf{X}$ & $\mathbf{X}$ & $\mathbf{X}$ & \\
\hline Total & $\mathbf{X}$ & $\mathbf{X}$ & $\mathbf{X}$ & \\
\hline
\end{tabular}

Fig.1. External Strategy Factor Matrix (EFAS)

\begin{tabular}{|l|c|c|c|l|}
\hline $\begin{array}{c}\text { Internal } \\
\text { strategy } \\
\text { factor }\end{array}$ & Weight & Rating & $\begin{array}{c}\text { Weight } \\
\mathbf{X} \\
\text { Rating }\end{array}$ & Information \\
\hline Power & $\mathbf{X}$ & $\mathbf{X}$ & $\mathbf{X}$ & \\
\hline Total & $\mathbf{X}$ & $\mathbf{X}$ & $\mathbf{X}$ & \\
\hline Weakness & $\mathbf{X}$ & $\mathbf{X}$ & $\mathbf{X}$ & \\
\hline Total & $\mathbf{X}$ & $\mathbf{X}$ & $\mathbf{X}$ & \\
\hline Total & $\mathbf{X}$ & $\mathbf{X}$ & $\mathbf{X}$ & \\
\hline
\end{tabular}

Fig.2. Internal Strategy Factor Matrix (IFAS)

\subsection{SWOT Matrix}

The tool used to compile the strategic factors of the organization is the SWOT matrix. This matrix can clearly describe how the external opportunities and threats faced by the organization can be adjusted to the strengths and weaknesses it has. This matrix can produce 4 sets of possible strategic alternatives (Saaty, 1980).

a. Strategies (Strength-Opportunities) This strategy is based on the mindset of the organization, namely by utilizing all the power to seize and take advantage of the greatest opportunities

b. ST Strategy (Strenghts-Threats) It is a strategy to use the strength of the organization to overcome threats.

c. WO (Weknesses-Opportunities) Strategy This strategy is implemented based on utilization opportunities that exist in a way minimize existing weaknesses. d. WT Strategy (Weknesses-Threats) This strategy is based on defensive activities and seeks to minimize existing weaknesses and avoid threats.

\begin{tabular}{|c|c|c|}
\hline IFAS EFAS & \begin{tabular}{|l} 
STRENGHT \\
(S) \\
Determine 5-10 \\
factors of internal \\
strength
\end{tabular} & $\begin{array}{l}\text { WEAKNESS } \\
\text { (W) } \\
\text { Determine 5-10 } \\
\text { internal } \\
\text { weaknesses }\end{array}$ \\
\hline $\begin{array}{l}\text { OPPORTUNITIES (O) } \\
\text { Determine 5-10 } \\
\text { external threat factor }\end{array}$ & $\begin{array}{l}\text { STRATEGY } \\
\text { So } \\
\text { Create a strategy } \\
\text { that } \\
\text { use } \\
\text { the power to take } \\
\text { advantage of } \\
\text { opportunities }\end{array}$ & $\begin{array}{l}\text { STRATEGY } \\
\text { WO } \\
\text { Create } \\
\text { strategies that } \\
\text { minimize } \\
\text { weaknesses to } \\
\text { take advantage } \\
\text { of opportunities }\end{array}$ \\
\hline $\begin{array}{l}\text { THREATS }(\mathrm{T}) \\
\text { Determine } 5-10 \text { external } \\
\text { threat factors }\end{array}$ & $\begin{array}{l}\text { STRATEGY } \\
\text { ST } \\
\text { Create a strategy } \\
\text { who uses it } \\
\text { the power to } \\
\text { Overcome threats }\end{array}$ & $\begin{array}{l}\text { STRATEGY } \\
\text { WT } \\
\text { Create } \\
\text { strategies that } \\
\text { minimize } \\
\text { weaknesses } \\
\text { and avoid } \\
\text { threats }\end{array}$ \\
\hline
\end{tabular}

Fig.3. diagram Swot matric II. 4

\subsection{Development Strategy}

The success of a predetermined strategy is largely determined by how much the level of suitability of the strategy is with changes in the environment, competitors, and organizational situation factors in formulating a strategy (Gorener, Toker, \& Korkmaz, 2012):

In Conditions of Strong Competition Position Strengthens the Power of Development.

a. Type of Development Strategy

To find out its competitiveness in every power, Porter advises organizations to use one of three strategies: differentiation, cost leadership, or focus. Organizational characteristics that can be associated with each strategy.

1) Differentiation Strategy

2) New competitors through customer loyalty that are difficult to overcome.

3) Focus Strategy Leadership Strategy

b. Formulating a Development Strategy

An effective way to formulate a strategy is the five strengths and development strategies (Kangas, Pesonen, \& Mikko, 2001). Researching a number of organizations and stating that business-level strategies are the result of five developmental strengths within the organization.

Five Porter Development strengths. The development forces that exist within the organization and show the influence of internet technology on each power.

These forces help determine the position of the organization versus its competitors in the industrial world.

1) New potential competitors.

2) Bargaining power of buyers 
3) The bargaining power of suppliers

4) Threat of replacement output

5) Inter-competitor competitors

\subsection{Research methods}

In this study the authors used a type of qualitative research with a descriptive approach that is a study that aims to make a systematic, factual and accurate enunciation of the facts and characteristics of the object of research (Devi Cipta Anggraini, 2018). Descriptive statistics are statistics that function to describe or give an overview of the object under study through sample data or population as it is, without doing analysis and making conclusions that apply to the public (Arica dwi susanto, 2019). Bogdan and Biklen in propose five characteristics of a qualitative study, namely (Hunger \& Wheelen, 2010):

a. Qualitative research is carried out on a natural setting as a direct data source and research is a key instrument

b. It is descriptive in that it describes a particular situation or data collected in the form of words rather than numbers

c. Pay more attention to the process than the results or output alone

d. In analyzing data tends to be inductive

e. Meaning is essential for qualitative research

Sample research is part of the employee An organization of several existing employees, researchers took 10 employees who have the potential to provide accurate data or information. The reference for filling out this questionnaire is as follows:

Current conditions of research: assessment of handling urgency:

a. Very good with scores: 4

b. Good with a score: 3

c. Enough with a score: 2

d. Less with a score: 1

e. Number 1: not ugren

f. Number 2: lack of ugren

g. Number 3: ugren

h. Number 4: very ugly

To obtain accurate data that can be trusted by the truth and relevant problems examined, the data collection is done by several methods: Interview, Observation, Questionnaire, Literature study. Operational variables are everything in the form of what is determined by the researcher to be studied so that information about it is obtained, then conclusions are drawn (Mehmet, 2011). The variables in this study are independent variables (free) and dependent variables (bound). Free variable (independent variable) or variable $X$ is often also called a stimulus variable, predictor, antecedent. the independent variable is a variable that affects or which is the cause of the change or the emergence of the dependent variable. In this study independent variables are the four constituent elements of SWOT, which include:

a. Strengths as $\mathrm{X} 1$

\section{b. Weaknesses, as $\mathrm{X} 2$ \\ c. Opportunities as $\mathrm{X} 3$ \\ d. Threaths as $\mathrm{X} 4$}

Dependent variable (dependent variable) or variable $\mathrm{Y}$ ) is often also called the output variable, criteria, consequently. Dependent variable is a variable that is influenced or that becomes a result, because of the existence of independent variables. Which is the dependent variable (independent variable) in this research is a development strategy.

\subsection{Data analysis method}

The analysis in this study is to use SWOT analysis, where this method shows the performance of the organization by determining a combination of internal and external factors'. SWOT analysis compares internal factors, namely strength (weakness), and weakness (weakness). With external factors, namely opportunities and threats. Internal factors are included in the matrix called IFAS factor matrix (Internal Strategic Factor Analysis Summary). External factors are included in the matrix called the external factor matrix or EFAS (External Strategic Factor Analysis Summary). After the internal and external strategy factor matrix was completed, the results were entered into a qualitative model, namely the SWOT matrix to formulate an organizational development strategy. The internal strategy (IFAS) and external matrix (EFAS) matrix.

\subsection{Research Methodology Flowchart.}

To solve problems in the observed research, steps are needed and determined to describe the approach and model of the problem. The steps taken are:

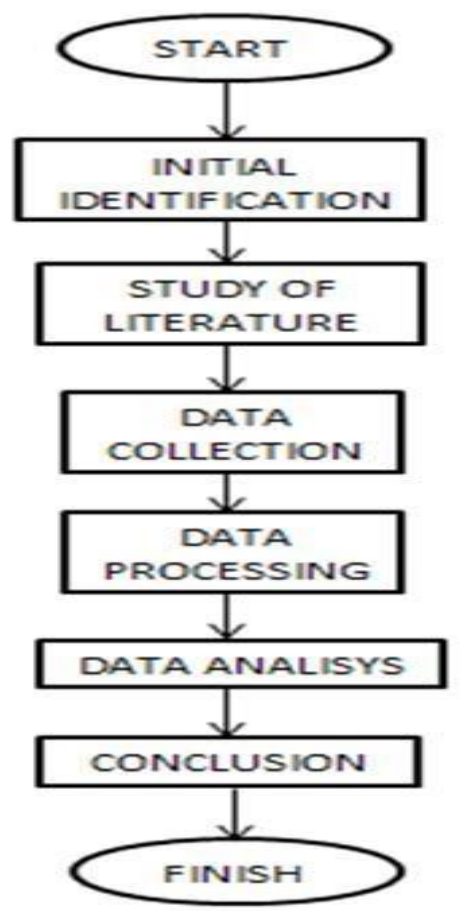

Fig.4. Research Methodology Flowchart. 
Target: the purpose of this study is to formulate an organizational development strategy in order to develop and compete in the midst of global flows so that users can obtain optimal results. The stages can be explained as follows:

a. Defining the problem

Before a decision support system is built, problems in research must be precisely defined so that the results obtained are in accordance with the problem at hand.

b. Data collection.

Data collection was obtained by conducting a literature study of the SWOT method used in research to determine the influence of internal and external influences obtained from several literatures such as journals, books and other scientific sources that are related and relevant to research.

c. Identification and processing of data at this stage of identification and processing of data that has been obtained will be carried out.

d. System Analysis and Design Perform analysis and system design in accordance with identified problems.

e. System Implementation.

At this stage, the system will be implemented in accordance with the concept prepared in the previous stage. The final step provides suggestions for improvement and conclusions.

\section{RESULTS AND DISCUSSION}

\subsection{RESULTS}

From the results of the SWOT analysis includes strengths, weaknesses, opportunities and threats to an organization, namely: Strength of an organization that is

a. Organizations that are well known to the public

b. Quality service.

c. Delivery of goods that are always on time.

d. Cheap but high-quality prices that make a difference from other organizations.

e. Relationship of leaders with good employees.

Weaknesses of an organization are:

a. Most activities are carried out manually

b. Not so much about promoting new customers

c. There is still a defective item of around $15 \%$

d. Rarely do machine maintenance opportunities for an organization, namely:

e. Organizations that have regular customers

f. There are still many opportunities because of potential customers

g. The occurrence of internet development that aims to improve communication with clients and suppliers that will help increase output.

h. With the addition of employees who will help service and income of the organization.

The threat of an organization is:

a. Many competitors close to the organization

b. Competitors who have the capacity and wide range c. Fluctuating prices of raw materials

d. Slow user growth

e. Customers who have sensitivity to the price of goods that can move to competitors that offer low prices.

\subsection{DISCUSSION}

After knowing the strengths, weaknesses, opportunities and threats to the next organization will be analyzed against these factors to get a further picture of the conditions at the organization's output to the community so that strategies and steps can be determined that can be applied in the future. The first step in the analysis phase of the factors of strength, weakness, opportunity and threat of the Organization is to do an analysis through the IFAS matrix (Internal Strategic Factor Analysis Summary) and EFAS (External Strategic Factor Analysis Summary).

Furthermore, from the results of the analysis using the IFAS and EFAS matrices, it will be analyzed using a SWOT diagram to get an overview of the end of the organization's output with similar outputs from other organizations.

Internal Strategy Factor Matrix (IFAS) and External Strategy Factor Matrix (EFAS). After the internal and external strategy factors of an organization are identified, an IFAS and IFAS table is prepared to formulate these internal strategy factors in the framework of Strength and Weakness. Organizations from the results of observations and interviews on questionnaires on the respondents selected, then with calculations as in the following table to determine the weight value, rating and score. Alternative strategy formulation.

Next to formulate alternative strategy formulations An organization uses the SWOT matrix. alternative strategies are prepared based on the interaction of internal and external factors of the organization to obtain a development strategy. Some alternative strategies that can be done by the organization, Development strategies for an organization Based on the results of analysis using the SWOT matrix of several internal factors, in the form of strengths and weaknesses, and external factors such as opportunities and threats to determine the development strategy for an organization is to diversify (output, user), namely : ST - strategy.

a. Organizations that are already known to the public will provide positive value for the organization so that users remain loyal to the Organization.

b. Improve quality, shuttle service and expand coverage to outside the city/Java with internet promotions and services.

c. Conduct paper stock strategies to anticipate the surge in prices of paper raw materials

d. Improve promos with the principle of 'quality low price' to reach as many customers as possible and with training and mastery of technology which are the main causes. As well as resources 
e. Guarantee the quality of paper and the perfect prints by checking manually at low prices so that users do not move to competition.

\section{CONCLUSION}

From the results of SWOT internal and external analysis An organization to obtain a development strategy can be concluded as follows:

a. SO STRATEGY: Improve quality and service so that users feel satisfied and comfortable and attract new users, Increase organizational capacity by utilizing teamwork capabilities and organizational experience to reach potential users

b. ST STRATEGY: Organizations that are already known to the public will provide positive value to the organization so that users remain loyal to the Organization, Quality, shuttle service and expanding coverage to outside the city / Java with internet promotions and services, Conduct paper stock strategies to anticipate the surge in prices of paper raw materials, Ensure the quality of paper and the perfect printout by checking manually at low prices so that users do not move to competitors.

c. WO STRATEGY: Buy new machines and add employees to simplify and speed up the output process, By further increasing promotion through the internet as well as agencies such as schools, shops or organizations will indirectly provide information to new users.

d. WT STRATEGY: Increase the number of marketing employees on duty to come directly to the user, Suppress the existence of defective goods to produce quality and cheap output prices, Creating an organization website to introduce output output to the user

e. SWOT ANALYSIS: After identifying what is in an organization, using SWOT analysis, namely IFAS, IFAS and SWOT matrix. So it was concluded that an organization has a very strategic position to support the development of obtaining a strategic advantage. An organization is located in squared I, meaning that at this position the output of an organization is very supportive for an aggressive growth strategy to gain organizational excellence to compete with other organizations. One method of strategy that can be implemented is to create distinctions or distinctions from other organizations using the S-T strategy.

To solve problems in the observed research, steps are needed and determined to describe the approach and model of the problem.

\section{REFERENCES}

Arefeh Jamshidi, S. N. (2012). SWOT Analysis of strategic Position of Cycling Federation in Iran. International Journal of Academic Research in Business and Social Sciences , 2 (5), 106-113.

Arfan Arshad, M. F. (2017). A Synthesis on SWOT Analysis of Public Sector Healthcare Knowledge Management Information Systems in Pakistan. (IJACSA) International Journal of Advanced Computer Science and Applications , 8 (8), 131-136.

Arica dwi susanto, N. S. (2019). Business Development Strategy Analysis PT. X Using the SWOT Method. International Journal of Academic and Applied Research (IJAAR) , 49.

Arys Susanto, A. D. (2018). Optimization of the ANP and Set Covering Method for the Allocation of Tanker in the East Sea Region of Indonesia. International Journal of ASRO-STTAL , 63-74.

Bello, N. A. (2013). Strengths, Weaknesses, Opportunities And Threats (SWOT) Analysis On Globacom Ltd. International Journal of Information Technology and Business Management , 16 (1), 83-91.

Boonyarat Phadermrod, R. M. (2016). ImportancePerformance Analysis based SWOT analysis. International Journal of Information Management , 1-34.

C.Kiritharan nair, P. (2016). Development of Strategic Plan for Hotel Industries through Swot Analysis. SSRG International Journal of Mechanical Engineering (SSRG-IJME) , 3 (3), 6-10.

Chermack, T. J., \& Kasshanna, B. K. ( 2007). The use and misuse of SWOT analysis and implications for HRD professionals. Human Resource Development International , 383399.

Clardy, A. (2013). Strengths vs. Strong Position: Rethinking the Nature of SWOT Analysis. Modern Management Science \& Engineering , 1 (1), 100-122.

Devi Cipta Anggraini, S. A. (2018). Implementation of SWOT-ANP Method to Determine the Best Strategy on Development Women Navy Resources in Indonesia War Ship. International Journal of Academic Multidisciplinary Research (IJAMR), 11-20.

Dyson, R. G. (2004). Strategic development and SWOT analysis at the University of Warwick. European Journal of Operaional Research , 631-640.

GÖRENER, A. (2012). Comparing AHP and ANP: An Application of Strategic Decisions Making in a Manufacturing Company. International Journal of Business and Social Science , 3 (11), 194-208.

Gorener, A., Toker, K., \& Korkmaz. (2012). Application of Combined SWOT and AHP : A Case Study for a Manufactruring Firm. 
Procedia - Social and Behavioral Science, 1525-1534.

Hajikhani, A., \& Jafari, H. R. (2013). Developing a Mix Method of a SWOT, BSC and QFD toward strategic Planning. Interdisciplinary Journal of Contemporary Research in Business , 476-489.

Hasan Hosseini-Nasab, A. H.-N. (2011). Coping with Imprecision in Strategic Planning: A Case Study Using Fuzzy SWOT Analysis. iBusiness , 3, 23-29.

Hunger, J. D., \& Wheelen, T. L. (2010). Essentials Of Strategic Management 5th edition. United States of Amerika: Prentice Hall.

Husni Thamrin, R. H. (2017). A SWOT Analysis Tool For Indonesian Small and Medium Enterprise. ARPN Journal of Engineering and Applied Sciences , 12 (2), 620-625.

Hutabarat, L. F. (2017). Indonesian Female Peacekeepers in the United Nations Peacekeeping Mission. Jurnal Pertahanan , 185-206.

Kahraman, C., Cetin, N., \& Demirel, T. (2007). Prioritiation of e-Govrnment strategies using a SWOT-AHP analysis: the case of Turkey. European Journal of Information System , 284-298.

Kangas, J., Pesonen, M., \& Mikko. (2001). A'WOT:Integrating the AHP with SWOT analysis. ISAHP, 189-197.

Kotnal, J. R. (2017). Strategic Planning \& SWOT Analysis. International Journal of Advanced Research and Development , 2 (6), 60-62.

Lalitha Chavali, D. P. (2017). Swot Analysis. International Journal of Management and Applied Science , 3 (4), 50-51.

Leila Asayesh, H. K. (2013). Studying strategies of sport management using SWOT technique. European Journal of Experimental Biology , 3 (6), 54-60.

Lumaksono, H. (2014). Implementation of SWOTFAHP method to determine the best strategy on development of traditional shipyard in sumenep. Academic research international, 56-67.

Mehmet, E. (2011). A Fuzzy Multi-criteria SWOT Analysis: An application to nuclear power plant site selection. International Journal of Computational Intelligence Systems, 583595.

Osuna, E. E., \& Aranda, A. (2007). Combining SWOT and AHP Techniques for strategic planning. ISAHP , 1-8.
Pereira, C. S. (2015). Pereira Diamond: Benefits Management Framework. The International Journal Of Business \& Management, 3 (3), 47-56.

Pershing, J. A. (2006). Handbook of Human Performance Technology. San Fransisco: Pfeiffer.

Rangkuti., F. (2012). SWOT Balanced Scorecard. Jakarta: PT Gramedia.

Ronen, A. C. (2009). Focused SWOT: diagnosing critical strengths and weaknesses. International Journal of Production Research , $47(20), 5677-5689$.

Saaty, T. (1980). The Analytical Hierarchy Process. New York: McGraw-Hill.

Sentot Patria. W. S, A. D. (2018). Performance Assessment of PT. X Automotive Companies Using Performance Prism and Analytical Hierarchy Process (AHP). SSRG International Journal of Economics and Management Studies (SSRG-IJEMS) , 11-18.

Setiarso, B. (2018). Determination of landing beach location for amphibious operations on the west papua sea with Analytic Hierarchy Process (AHP):case study on Sorong regency. Journal Of Defense Resources Management , 21-33.

Till, G. (2015). Indonesia as a growing maritime power: possible implications for Australia. Soundings Sea Power Centre , 1-13.

Tugba Yanpar YELKEN, F. K. (2012). The Strategic Planning (SWOT) Analysis Outcomes And Suggestions According to The Students And The Lecturers Within The Distance Education System. Turkish Online Journal of Distance Education , 13 (2), 267-276.

Ussahawanitchakit, P. P. (2011). Strategic Entrepreneurship Management Competency And Firm Success: A Comparative Study of SMEs in Auto And Electronic Parts in Thailand. International Journal of Business Strategy , 11 (2), 1-31.

Volkova, R. M. (2015). Strategic Innovation Application in Creative. Journal of Business Management (10), 15-27.

Yogi, P., Rizal, O., \& Ahmadi. (2017). Feasibility Analysis of Naval Base Relocation using SWOT and AHP method to support main duties operation. Journal of Defense management , 14-30. 